27. Новітне вчення про тлумачення правових актів : навч. посібник 3 курсу тлумачення прав. актів для суддів, що проходять підвищення кваліфікації, і кандидатів на посади суддів, що проходять спеціальну підготовку / В.Г. Ротань, І.Л. Самсін, А.Г. Ярема та ін.; за ред.: В.Г. Ротань. Харків : Право, 2013. 751 с.

УДК 340.136

DOI https://doi.org/10.32844/2618-1258.2019.5-1.2

БЕЗУСА Ю.О.

\title{
ДО ПИТАННЯ ПРО ВИДОВУ ХАРАКТЕРИСТИКУ ПРАВОВИХ КОЛІЗІЙ
}

У статті подається аналіз широкого спектру правових колізій, що існують у межах конкретної національної правової системи. Звертається увага на те, що правові колізії свідчать не тільки про недосконалість законодавства, а й указують на його розвиток. Зазначено, що юридична колізія і колізія в законодавстві - поняття різні, передусім за своїми обсягами. Юридична колізія охоплює собою всі протиріччя, що виникають у правовій системі суспільства, зокрема у правових концепціях, теоріях і поглядах, правосвідомості і правовій культурі, правоутворенні і реалізації норм права, правовій поведінці, законності і правопорядку, праворозумінні. Колізії в законодавстві $є$ лише частиною юридичних колізій і обмежуються системою законодавства. Далі аналізуються види колізій у законодавстві. Визначено, що у широкому сенсі правові колізії є суперечностями між правовими нормами, нормативно-правовими актами, правовими поглядами, компетенцією органів державної влади (органів місцевого самоврядування), актами застосування права, правовими системами. У вузькому сенсі правові колізії розглядаються як суперечності між правовими нормами або між правовими актами. Правові колізії свідчать не лише про недосконалість законодавства, а й указують на його розвиток. Наголошено, що за характером причин, які породжують колізії, розрізняють: правові колізії, що виникають унаслідок розвитку самих суспільних відносин (рівень економічного розвитку, розвиненість інститутів громадянського суспільства, наявність інститутів демократії); правові колізії, що є наслідком дії суб'єктивних чинників (можливість знаходження соціального компромісу, боротьба за політичну владу, рівень правової культури населення, наукова обгрунтованість законодавства). 3'ясовано, що можливі колізії не лише всередині цього кола правових актів, а й між цими актами та нормативно-правовими актами. Очевидно, до юридичних колізій слід віднести й колізії між індивідуальними правовими актами, між такими актами та нормативними актами. Немає будь-яких підстав для того, щоб не відносити до юридичних колізій суперечності між окремими положеннями одного й того ж нормативного чи індивідуального акту.

Ключові слова: колізія у праві, колізія у законодавстві, вертикальні колізії, темпоральна колізія, змістовна колізія, колізія у правозастосуванні, колізія цілей нормативних актів, правові суперечності, індивідуальні акти.

The article analyzes a wide range of legal conflicts that exist within a particular national legal system. Attention is drawn to the fact that legal conflicts indicate not only the imperfection of the legislation, but also indicate its development. Attention is drawn to the fact that legal conflict and conflict in legislation - the concepts are different and, above all, in their scope. Legal conflict covers all the contradictions that arise in the legal

(C) БЕЗУСА Ю.О. - кандидат юридичних наук, доцент кафедри теорії та історії держави та права (Харківський національний університет внутрішніх справ) 
system of society, in particular in legal concepts, theories and views, legal awareness and legal culture, lawmaking and implementation of law, legal behavior, law and order, legal understanding. Conflicts in legislation are only part of legal conflicts and are limited to the legal system. Next, the types of conflicts in the legislation are analyzed. It is determined that in a broad sense, legal conflicts are contradictions between legal norms, regulations, legal views, the competence of public authorities (local governments), acts of law, legal systems. In a narrow sense, legal conflicts are considered as contradictions between legal norms or between legal acts. Legal conflicts indicate not only the imperfection of the legislation, but also indicate its development. It is emphasized that by the nature of the causes that give rise to conflicts, there are: legal conflicts that arise as a result of the development of social relations themselves (level of economic development, development of civil society institutions, the existence of democratic institutions); legal conflicts that are the result of subjective factors (the possibility of finding a social compromise, the struggle for political power, the level of legal culture of the population, the scientific validity of the legislation). It was found that conflicts are possible not only within this range of legal acts, but also between these acts and regulations. Obviously, legal conflicts should include conflicts between individual legal acts, between such acts and regulations. There is no reason not to refer to legal conflicts as contradictions between individual provisions of the same normative or individual act.

Key words: conflict in law, conflict in legislation, vertical conflicts, temporal conflict, substantive conflict, conflict in law enforcement, conflict of goals of normative acts, legal contradictions, individual acts.

Вступ. Постановка проблеми про видову багатоманітність правових колізій детермінована сутнісними характеристиками права, необхідністю постійної відповідності юридичних законів потребам суспільного розвитку, внаслідок чого збільшується як сама система правових знань, так і кількість нормативно-правового матеріалу. Зважаючи на це, поступово розвиваються наукові уявлення про природу правової колізії, яка має різноманітні форми прояву. Поряд із цим збільшується питома вага наукових знань у цій сфері. У цьому зв'язку необхідність узагальнення накопичених знань, рівно як і формування нових у царині правових колізій, спричиняє аналіз їхньої видової характеристики.

Для юридичної науки питання правових колізій унаслідок складності та фундаментальності $є$ споконвічним, таким, що перебуває у полі зору багатьох вітчизняних та зарубіжних учених, адже інтенсивне збільшення масиву позитивного права, як і його динамізм, неминуче породжує ті чи інші суперечки, що зумовлює вивчення їх видової багатоманітності.

Своєю чергою, у вітчизняній юриспруденції питанню видової характеристики правових колізій присвячено публікації В. Андрейцева, В. Бойка, Ф. Бурчака, П. Євграфова, В. Єрьоменка, А. Зайця, О. Зайчука, М. Козюбри, Я. Ленгер, Д. Лилака, О. Капліної В. Копейчикова, О. Розгон, П. Погребянка, А. Портнова, Н. Свиридюка, В. Шкабаро, С. Рибіної.

Водночас, зважаючи на вищезазначене, питання про видову характеристику правових колізій усе ще потребує пильної уваги вчених та має високий рівень актуальності.

Постановка завдання. Метою статті є аналіз видової багатоманітності правових колізій для визначення шляхів їх усунення в позитивному праві.

Результати дослідження. Насамперед слід погодитися з думкою Я. Ленгер, котра звертає увагу на те, що в радянський період розвитку юридичної науки термін «колізія» вживався тільки щодо норм права (розрізняються колізії між правовими нормами, між нормами права й актами тлумачення (положеннями постанов пленумів Верховних судів) [1, с. 99-100]. Під час дослідження правової надбудови у функціонуванні та розвитку права М. Баймаханов виділяє суперечності матеріальні (між суспільними відносинами, з одного боку, і спрямованими на їх регулювання правовими інститутами і нормами - з іншого) і формальні (колізії в самому праві між інститутами і нормами) [1, с. 99-100; 2, с. 215-216]. Однак колізіями він називає тільки формальні суперечності. Починаючи з 90-х років і дотепер вчені широко використовують термін «юридична колізія», яким характеризують не лише неузгодженість норм, а й суперечності між різними правовими явищами $[1$, с. 99-100]. Таким чином, дослідження правових колізій в юридичній науці дає змогу говорити про їх багатоаспектний характер. У широкому сенсі правові колізії є суперечностями між правовими нормами, нормативно-правовими актами, правовими 
поглядами, компетенцією органів державної влади (органів місцевого самоврядування), актами застосування права, правовими системами. У вузькому сенсі правові колізї розглядаються як суперечності між правовими нормами або між правовими актами. Правові колізії свідчать не тільки про недосконалість законодавства, а й указують на його розвиток. Усуваються такі суперечності (невідповідності) застосуванням загальноправових принципів і спеціальних процедур вирішення правових колізій [1, с. 120]. Це дає підстави стверджувати, що юридична колізія і колізія у законодавстві - поняття різні, передусім за своїми обсягами. Юридична колізія охоплює собою всі протиріччя, що виникають у правовій системі суспільства, зокрема в правових концепціях, теоріях і поглядах, правосвідомості і правовій культурі, правоутворенні і реалізації норм права, правовій поведінці, законності і правопорядку, праворозумінні. Колізії у законодавстві $є$ лише частиною юридичних колізій і обмежуються системою законодавства [3].

Водночас необхідно відзначити, що колізія між нормами позитивного права виникає за чотирьох умов:

1) наявність двох або більше норм права;

2) норми права повинні регулювати одні й ті ж суспільні відносини;

3) норми права повинні бути одночасно чинними;

4) положення, що містяться в одній нормі права, повинні суперечити, відрізнятися до положень, що містяться в іншій нормі права. Таким чином, колізія норм права - це розбіжність змісту у формі протиріччя або відмінності двох і більше одночасно діючих норм права, що регулюють одні й ті ж суспільні відносини [4, с. 55].

У фаховій літературі наголошується, що найповнішу та науково обгрунтовану класифікацію правових колізій у законодавстві запропонували М. Власенко та Ю. Тихомиров, класифікуючи їх за такими критеріями: за властивостями та особливостями норм, що конфліктують, - темпоральні, просторові, ієрархічні, змістовні; за ступенем зіткнення правових норм - суперечності та відмінності [5, с. 27]. При цьому вченими вказується, що:

1) темпоральні (часові) - такі, що виникають унаслідок видання в різний час із того ж самого питання принаймні двох норм права;

2) ієрархічні (субординаційні), специфіка яких полягає у тому, що на врегулювання одних фактичних відносин претендують норми, що знаходяться на різних щаблях в ієрархічній (вертикальній) структурі законодавства і тому мають різну юридичну силу;

3) змістовні колізії, котрі являють собою конфліктні відносини між нормами, що виникають у результаті часткового збігу обсягу їх регулювання, зумовленого специфікою суспільних відносин.

Цей підхід знайшов свій подальший розвиток у наукових публікаціях багатьох дослідників, які опановують проблематику правових колізій. У літературі підкреслюється, що найпоширенішими у правозастосовній практиці є саме темпоральні або часові правові колізії, які виникають у ситуації, коли для регулювання одного й того самого правовідношення у різний час приймаються різні правові норми. У такій ситуації визначальним є напрям темпоральної чинності нормативно-правового акта, в якому міститься норма: дія норми може бути прямою, коли норма поширюється на факти, які виникли після набрання нею чинності або до набрання нею чинності та продовжують існувати; зворотною - коли норма поширюється на факти, які виникли до набрання нею чинності вже з моменту їх виникнення; дія норми може бути переживаючою, коли дія норм поширюється лише на нові факти [6; 7, с. 108].

Безперечно, під час прийняття кожного нового нормативно-правового акта має відбуватися скасування та зміна усіх інших актів, що йому суперечать. Проте з ускладненням правового регулювання, враховуючи наявність тисяч нормативно-правових актів, що потенційно можуть містити конфліктуючі норми, забезпечення такого ідеалу є недосяжним, але до нього слід прагнути [6; 8, с. 17].

Існування темпоральних колізій зумовлюється переважно припиненням дій правових норм шляхом заміни їх пізнішою, яка регулює ті самі правовідносини. Для подолання темпоральних колізій використовується відомий ще з часів римського права колізійний принцип lex posterior derogate priori («пізнішим законом відміняється більш ранній»). Застосування цього колізійного принципу грунтується на припущенні розумності законодавця: «законодавець завжди мислить послідовно і ніколи не допускає протиріччя із самим собою», тобто в контексті подолання темпоральних колізій це припущення означає, що, видавши нову норму, законодавець тим самим прагнув скасувати стару норму [6; 9 с. 6-7]. Цей підхід також поділяють О.А. Теличко та Н.В. Іванюк, указуючи на те, що, згідно з темпоральним способом вирішення колізій, перевага надається 
акту, прийнятому пізніше. У разі регулювання одних відносин за наявності двох нормативних актів однакової юридичної сили той, який прийнятий пізніше, скасовує дію попередніх [10].

За юридичною силою норм, які перебувають у колізії, виокремлюють колізії однакової юридичної сили та норми різної юридичної сили [6; 5 с. 27]. При цьому, як зауважує Н. Свиридюк, однією з найпоширеніших колізій є протиріччя між законами і підзаконними актами, які мають масовий характер саме в періоди реформ і $є$ потенційним джерелом великої шкоди інтересам людини, держави й громадянського суспільства, підривають авторитет права і можуть викликати як політичні, так і державно-правові конфлікти. Вирішення такого роду юридичних конфліктів має здійснюватися виключно в межах законів та на їх користь, оскільки вони мають верховенство та вищу юридичну силу. Окрім того, щоб скасувати колізію, потрібні не тільки висока майстерність законодавців, професіоналізм осіб, які займаються правотлумаченням і правозастосуванням, а й аналіз обставин справи та вибір єдино можливого (чи найбільш доцільного) варіанту рішення [11].

Під час подолання змістовних колізій застосовується колізійний принцип lex specialis derogat generalis («спеціальний закон відміняє (витісняє) загальний закон»), який грунтується на презумпції розумності законодавця. У контексті колізійності принципу lex specialis це припущення означає: «прийняття спеціальної норми свідчить про наявність спеціальної цілі законодавця - врегулювати певний різновид суспільних відносин інакше, ніж загальна норма». Змістовні колізії здебільшого створює законодавець свідомо для диференціації правового регулювання, якого досягають створенням спеціальних норм. Тобто спеціальні норми покликані відображати особливості і характерні риси суспільних відносин. Спеціальні норми видаються зі спеціальною метою регулювання визначених відносин, і лише в межах своєї дії вони забезпечують досягнення конкретної цілі [6; 9, с. 7-8]. Отже, змістовний спосіб вирішення колізій передбачає, що спеціальний закон скасовує дію загального. Загальні норми, як правило, поширюються на відносини загалом; спеціальні діють тільки в межах визначеного виду відносин і встановлюють для нього певні особливості порівняно із загальним правилом [10]. При цьому варто зауважити, що йдеться не про весь закон, а про конкретну правову норму чи ії частину, за змістом якої визначається, $є$ ця норма загальною чи спеціальною [10].

Окрім того, в юридичній літературі залежно від причин виникнення і ролі в правовій системі запропоновано класифікувати колізії норм права на позитивні та негативні (або закономірні й аномальні); залежно від ступеня складності - на прості та складні; залежно від форми вираження норм, що стикаються, - колізійні норми права, які містяться в одному нормативно-правовому документі й у різних джерелах права, а також колізії між нормами однієї галузі права і декількох галузей (внутрішні і міжгалузеві колізії) [12].

Поруч із цим варто звернути увагу на те, що в теоретико-правовій літературі наголошується на необхідності розмежування таких суміжних правових явищ, як «правова колізія» та «конкуренція правових норм». При цьому наголошується, що в колізії знаходяться норми, які суперечать одна одній, для колізій характерна наявність декількох норм, які відрізняються за змістом одна від одної. За конкуренції норм ніякої колізії не може бути. Можливі два види конкуренції: загальної та спеціальної норми. Зазначимо, що конкуренція - це більш складне явище, ніж колізія. У ній переплітаються питання факту з питанням права. Від колізій правових норм слід відрізняти їх конкуренцію, коли дві, три і більше норм регулюють одне й те ж коло споріднених суспільних відносин і не суперечать одна одній та наділені різним ступенем конкретизації, деталізації, обсягу і т. д. Це, як правило, норми різної юридичної сили, рівня, які виходять від нерівнозначних правотворчих органів. У таких випадках норми дійсно ніби конкурують між собою, і це в принципі нормально. Негативним же i, безумовно, небажаним явищем виступають саме колізії, коли стикаються один з одним не просто неузгоджувані, а й нерідко взаємовиключні приписи [13].

Продовжуючи характеризувати правові колізії, необхідно звернути увагу на думку М. Матузова, який пропонує розділити юридичні колізії на шість родових груп:

1) колізії між нормативними актами або окремими правовими нормами;

2) колізії у правотворчості (безсистемність, дублювання, видання актів, що виключають один одного);

3) колізії у правозастосуванні (різнобій у практиці реалізації тих самих приписів, неузгодженість управлінських дій);

4) колізії повноважень і статусів державних органів, посадових осіб;

5) колізії цілей (коли цілі нормативних актів різних рівнів та органів суперечать одна одній);

6) колізії між національним та міжнародним правом [4, с. 54; 14, с. 231$]$. 
Усі перелічені види юридичних колізій об'єднує спільна риса: вони виникають із приводу різних правових актів та правових норм і призводять до внутрішньої неузгодженості системи. Отже, колізії у законодавстві - це лише частина можливих юридичних колізій.

Так, залежно від правових форм діяльності, під час здійснення яких виникають юридичні колізії, можна говорити про: колізії у правозастосуванні (колізії між різними правозастосовними актами, колізії між нормативно-правовими актами і правозастосовними актами); колізії між різними правовими нормами законодавства (колізії у правотворчості). Це можуть бути і суперечності між законодавством та іншими джерелами права; колізії між окремими актами тлумачення (колізії між нормативно-правовими актами й актами тлумачення, колізії між правозастосовними актами й актами тлумачення); колізії між іншими елементами правової системи (наприклад, колізії між юридичною наукою та юридичною практикою) [4, с. 54].

За характером причин, які породжують колізії, розрізняють: правові колізії, що виникають унаслідок розвитку самих суспільних відносин (рівень економічного розвитку, розвиненість інститутів громадянського суспільства, наявність інститутів демократії); правові колізії, що є наслідком дії суб'єктивних чинників (можливість знаходження соціального компромісу, боротьба за політичну владу, рівень правової культури населення, наукова обгрунтованість законодавства). За юридичною силою нормативних актів, що містять колізійні норми (вертикальні колізії), виділяють: колізії норм національного законодавства та норм міжнародного права; колізії норм національного законодавства [4, с. 54].

На думку С. Погребняка, колізії правових норм, своєю чергою, можуть бути поділені на колізії між нормами права, які закріплені в законодавстві, та суперечності між нормами, закріпленими у законодавстві, й нормами, закріпленими в інших джерелах права (наприклад, суперечності між законодавством та правовими звичаями, нормативно-правовими договорами, правовими прецедентами). Тобто колізії у законодавстві $є$ різновидом колізій правових норм, які, своєю чергою, $є$ різновидом юридичних колізій, які розглядаються як різновид юридичних колізій, що виникають за наявності розбіжності (зокрема, суперечності) між реально або формально чинними нормами права, які закріплені в законодавстві та регулюють одні фактичні відносини [15, с. 26].

Цю думку, але в межах трудового права, розвиває В. Єрьоменко, котрий наголошує, що слід звернути увагу на ту обставину, що в Юридичній енциклопедії йдеться про колізії нормативних актів, а не тільки законів. У сфері трудового права до колізій нормативних актів слід додати колізії між колективними договорами й угодами, а у сфері цієї галузі права, а також цивільного і господарського права - також колізії між локальними нормативними актами.

Цілком зрозуміло, що можливі колізії не тільки всередині цього кола правових актів, а й між цими актами та нормативно-правовими актами. Очевидно, до юридичних колізій слід віднести і колізії між індивідуальними правовими актами, між такими актами та нормативними актами. Немає будь-яких підстав для того, щоб не відносити до юридичних колізій суперечності між окремими положеннями одного й того ж нормативного чи індивідуального акта [16].

Висновки. Аналіз класифікаційної характеристики правових колізій дає змогу наблизитися до формування універсальної дефініції цього поняття, під яким слід розуміти суперечність між правовим порядком, що існує, та намірами й діями щодо його зміни: це стан і дія кількох правових актів чи норм, як правило, нормативного характеру, прийнятих одним або різними суб'єктами правотворчості, спрямованих на регулювання одних і тих самих суспільних відносин, а застосування кожного з них окремо дає різний, у т. ч. протилежний, результат; це суперечність між правовими приписами відповідних актів, що виявляється у відмінностях у процесі регулювання аналогічних суспільних відносин.

\section{Список використаних джерел:}

1. Ленгер Я.І. Колізії в муніципальному праві: проблеми теорії та практики : дис. ... канд. юрид. наук. Ужгород, 2017. 432 с.

2. Баймаханов М.Т. Противоречия в развитии правовой надстройки при социализме. Алма-Ата : Наука (КазССР), 1972. 316 с.

3. Шкабаро В.М., Рибіна С.А. Деякі аспекти проблематики колізійності законодавства України. URL : http://legal.duan.edu.ua/images/stories/Files/2013/ARTICLES_2/22.pdf.

4. Розгон О.В. Сутність механізму вирішення колізій норм права. Eurasian academic research journal. 2016. № 1. C. 53-62. URL : http://www.earj.org.

5. Власенко Н.А. Коллизионные нормы в советском праве. Иркутск : Иркутский университет, 1984. 99 с. 
6. Василів С.С. Правові колізії підвідомчості розгляду справ про адміністративні правопорушення. URL : http://science.lpnu.ua/sites/default/files/journal-paper/2017/jun/4981/ vnulpurn201683730.pdf.

7. Рабінович П.М. Основи загальної теорії права і держави : навчальний посібник ; 3-є вид., змін. і доп. Київ : ІСДО, 1995. 100 с.

8. Мірошниченко А.М. Колізії в правовому регулюванні земельних відносин в Україні ; 2-е вид., перероб. і доп. Київ : Алерта ; КНТ ; ЦУЛ, 2010. 270 с.

9. Портнов А.В., Москалюк О.В. Види колізій у законодавстві України. Юрист України. 2012. № 1, 2. C. 5-12.

10. Теличко О.А., Іванюк Н.В. Причини виникнення колізій. URL : http://www.lj.kherson.ua/ 2016/pravo06/part_1/11.pdf.

11. Свиридюк Н.П. Юридичні колізії як властивість законодавства перехідного періоду. URL : http://www.apdp.in.ua/v58/12.pdf.

12. Капліна О.В. Колізії норм кримінально-процесуального права і шляхи їх подолання. URL : http://univer.km.ua/visnyk/1245.pdf.

13. Бойко В. Загальнотеоретичний аналіз співвідношення понять «колізія правових норм» та «конкуренція правових норм». URL : http://dspace.nbuv.gov.ua/bitstream/handle/ 123456789/39578/07-Boyko.pdf?sequence $=1$.

14. Матузов Н.И. Коллизии в праве: причины, виды и способы разрешения. Правоведение. 2000. № 5. C. 231-232.

15. Погребняк С.П. Про колізії в законодавстві. Вісник Академії правових наук України. 2003. № 1(32). C. 26-33.

16. Єрьоменко В.В. Поняття та види колізій в правовому регулюванні трудових та пов'язаних із ними відносин. URL : www.irbis-nbuv.gov.ua'irbis_nbuv'cgiirbis_64.

УДК 340.1

DOI https://doi.org/10.32844/2618-1258.2019.5-1.3

ВЕКЛИЧ В.О.

\section{НОРМИ ПРАВА І НОРМИ МОРАЛІ ЗА СУЧАСНИХ УМОВ: ПОТЕНЦІАЛ ДЛЯ РОЗВИТКУ АБО ДЕГРАДАЦІЇ}

У статті подано результати дослідження практичних особливостей норми права і норми моралі за сучасних умов, які пов'язані з їх регуляторним впливом на суспільні відносини. Встановлено деякі практичні особливості виникнення норм моралі та норм права, а також опрацьовано релевантний теоретичний матеріал, який стосується дефініцій окреслених норм. Подано загальну характеристику суспільних відносин за умов реалізації правового регулювання у зв'язку з опосередкованістю через узагальнені моделі з урахуванням однотипного характеру відповідних суспільних відносин. При цьому було враховано, що узагальненою вагомою особливістю норм права і норм моралі $€$ те, що концепт нормотворення у обох випадках опосередковано або прямо пов'язаний зі збереженням соціуму як сукупності індивідів, котрі перебувають у взаємозв'язку завдяки суспільним відносинам, що у своїй сукупності слугують основою виникнення, збереження та розвитку соціального середовища.

У контексті практичних особливостей цього дослідження закцентовано увагу на проблемах легалізації наркотиків та проституції як таких, що є практичним вираженням деградації норм права і моралі. Вказано на недоліки регуляторного впливу норм права на суспільні відносини за сучасних умов, а також закцентовано увагу на системному характері деструктивних тенденцій, пов'язаних з неврахуван-

( ) ВЕКЛИЧ В.О. - доктор юридичних наук, доцент кафедри конституційного права, історії та теорії держави і права (Навчально-науковий інститут права імені князя Володимира Великого Міжрегіональної Академії управління персоналом) 